\title{
Removal of Lead using Activated Carbon Derived from Red Algae (Gracilaria Changii)
}

\author{
Mubeen Isam ${ }^{1,}{ }^{*}$, Lavania Baloo ${ }^{1}$, Nasiman Sapari ${ }^{1}$, Idayu Nordin ${ }^{1}$, Saba Yavari ${ }^{1}$, and \\ Wesam Al-Madhoun ${ }^{1}$ \\ ${ }^{1}$ Department of Civil and Environmental Engineering, Universiti Teknologi PETRONAS (UTP), \\ 32610 Bandar Seri Iskandar Perak, Darul Ridzuan, Malaysia
}

\begin{abstract}
Red algae-derived activated carbon was evaluated for its ability to remove lead $(\mathrm{Pb})$ from synthetic aqueous solution. The activated carbon was prepared at a constant temperature of $300^{\circ} \mathrm{C}$ for 1 hour using a muffle furnace. Effect of $\mathrm{pH}$ contact time, initial ions concentration, and activated carbon dosage as important operating variables on the reaction process were also investigated. The batch experiment was conducted for adsorption experiment. The maximum lead uptake capacity was obtained at $\mathrm{pH} 6$ and operation time of $30 \mathrm{~min}$. the maximum uptake capacity of $\mathrm{Pb}$ (II) was found to be $0.1 \mathrm{mg} / \mathrm{g}$. This work confirms the potential use of red algae Gracilaria changii for the removal of heavy metals from wastewater.
\end{abstract}

\section{Introduction}

Pollution of water with heavy metals is a serious problem that endangers human health. If not managed and treated properly, heavy metals can accumulate in the food chain and cause major health. Heavy metals industries such as petroleum refinery, mining, and electroplating produce wastewater loaded with heavy metals that are discharged to the receiving environment directly or indirectly. The most common heavy metals are iron (Fe), chromium $(\mathrm{Cr})$, zinc $(\mathrm{Zn})$, cadmium $(\mathrm{Cd})$, cobalt $(\mathrm{Co})$, copper $(\mathrm{Cu})$, and lead $(\mathrm{Pb}) . \mathrm{Pb}$ is involved widely in industries such as lead batteries, explosive industries, paint and dyes, and electroplating[1]. A large quantity of lead ions is discharged into the environment[2]. According to EPA, allowable levels of $\mathrm{Pb}$ ions in drinking water is $0.015 \mathrm{mg} / \mathrm{L} \mathrm{[3].} \mathrm{Pb}$ has serious effects on the human nervous system and can cause a headache, hypertension, fatigue, anemia, and even death [3], [4].

Different methods have been used for removal of heavy metals from wastewaters such as ion exchange, chemical precipitation, membrane filtration, coagulation, and flocculation. These methods are either ineffective or expensive when heavy metals are in low concentrations. Other pitfalls are the complexity of the operation and large area requirement[5]. Adsorption is considered as an effective and relatively economical in the removal of heavy metals in wastewater. It can offer flexibility in both operation and design. Since adsorption is reversible, regeneration of adsorbent is also possible by desorption process [6]-[9] Adsorption using activated carbon can offer high efficiency due to the high

\footnotetext{
* Corresponding author: Mubeen.isam@gmail.com
} 
surface area, characteristics of surface chemistry, and a high degree of porosity. High costs of commercial activated carbon led to a growing research that aims to find cheaper alternatives. Adsorbents that are required little processing, by-products of another industry or abundant in nature can be considered low-cost materials [10]. Researchers have been focusing on producing low-cost adsorbents from carbonaceous materials such as hazelnut husk [11], rice husk [12], grape seeds [13], and palm solid waste [14]. and macroalgae [15][18]. Macroalgae showed a potential in removing heavy metals due to their small uniform particle size and number of different metal binding sites on the cell walls[19]. Red macroalgae can be found abundantly in coastal areas in Oceania, Africa and Asia[20]. Red algae Gracilaria changii is considered to be the most abundant macroalgae in Malaysia[21][23]. The utilization of such resource would also provide a favourable choice for controlling environmental degradation and eutrophication of oceans caused by algae[24]. This study aims to examine the performance of G.changii for the adsorption of $\mathrm{Pb}$ (II) from aqueous solution through batch adsorption experiment. Different operating parameters were investigated such as $\mathrm{pH}$, contact time, initial ions concentration, and activated carbon dosage.

\section{Materials and Methods}

\subsection{Chemicals and solutions}

The stock solution of $\mathrm{Pb}$ (II) $(1000 \mathrm{mg} / \mathrm{L})$ was prepared using lead chloride $\left(\mathrm{PbCl}_{2}\right)$ and then was diluted appropriately with distilled water to obtain desired concentrations. $0.1 \mathrm{M}$ of hydrochloric acid $(\mathrm{HCl})$ and $0.1 \mathrm{M}$ of sodium hydroxide $(\mathrm{NaOH})$ were used for $\mathrm{pH}$ adjustment. All used chemicals were of analytical grade, provided by Merck (KGaA, Darmstadt, Germany).

\subsection{Preparation of activated carbon}

Red macroalgae (Gracilaria changii) was collected from Fishery Department of Langkawi, Malaysia. The biomass was washed with tap water followed by distilled water to remove salt and other impurities. After that, the biomass was dried at $70^{\circ} \mathrm{C}$ for 24 hours in an oven. The dried biomass was grinded and sieved to a particle size of $300 \mu \mathrm{m}$ and then was pre-treated with $0.2 \mathrm{M} \mathrm{HCl}$. Thermal activation was carried out at a temperature of $300^{\circ} \mathrm{C}$ for 1 hour using a muffle furnace (Protherm PLF 110/45). The produced activated carbon was cooled and stored in glass bottles before use.

\subsection{Chemicals and solutions}

\subsubsection{Scanning electron microscopy (SEM)}

Scanning electron micrograph was analysed and clearly revealed by scanning electron microscopy (SEM, Supra 55 VP, Carl Zeiss-Germany) at a magnification (3000X).

\subsubsection{Adsorbent surface area}


The surface area of the adsorbent was determined through Brunauer-Emmett-Teller (BET) analysis (BET, TriStar II 3020, micromeritics-UK).

\subsubsection{Functional groups determination (FT-IR)}

Fourier transform infrared spectroscopy (FTIR, Spectrum one, Perkim Elmer-US) was used to determine the activated carbon functional groups involved in the adsorption process.

\subsection{Batch Adsorption Experiments}

Effects of operating variables including $\mathrm{pH}$ (2-8), contact time (10-120 min), initial ions concentrations $(5-20 \mathrm{mg} / \mathrm{L})$, and adsorbent dosage $(1-6 \mathrm{~g} / \mathrm{L})$ were evaluated on the activated carbon efficiency in removal of lead ions from aqueous solution.

Adsorption studies were conducted using batch equilibrium technique during which a 100 $\mathrm{mL}$ of a solution containing known initial ions concentration was mixed with a known amount of adsorbent $(0.1 \mathrm{~g})$. It was then shaken at $150 \mathrm{rpm}$ at room temperature $\left(25 \pm 1^{\circ} \mathrm{C}\right)$ using an orbital shaker (Protech Model 722). At the end of predetermined time, the mixture was filtered through Whatman's glass microfiber filter paper. The filtered solution was then analysed for the residual $\mathrm{Pb}$ (II) concentration using atomic absorption spectrometer (AAS, Model AA 6800 Shimadzu). Metal efficiency and adsorption capacity were calculated using Eq. 1 and Eq. 2, respectively.

$$
\mathrm{R}=\frac{C_{i}-C_{e}}{C_{i}} * 100 \%
$$

Where, $R$ is the $\mathrm{Pb}$ (II) removal efficiency (\%), $C_{i}$ is the initial lead ions concentration and $C_{e}$ is the residual concentration $(\mathrm{mg} / \mathrm{L})$ at equilibrium.

$$
\mathrm{Q}_{\mathrm{c}}=\frac{\left(C_{i}-C_{e}\right) * V}{W}
$$

Where $Q_{c}$ is the activated carbon adsorption capacity $(\mathrm{mg} / \mathrm{g}), V$ is volume of aqueous lead solution (L) and $W$ is the mass of the adsorbent (g).

\section{Results and Discussions}

\subsection{Adsorbent characteristics}

Fig. 1 shows morphology and surface texture of the red algae-derived activated carbon. Based on the figure, there were pores on the surface of the produced activated carbon. These pores were available for the metals ions to bind during the adsorption process. However, after undergoing adsorption of $\mathrm{Pb}$ (II), insignificant pores were observed on the surface of the activated carbon (refer Fig.1). After exposure of the adsorbent to heavy metals solution, the metals ions occupy the available free binding sites on the surface of activated carbon and can replace with some of the cations initially present on the adsorbent surface through ionexchange mechanism [25]. GCAC was subjected to elemental analysis before and after adsorption process are shown in table 1 . The results from BET analysis showed the value of 
BET surface area for the produced activated carbon under detection level of the analyser was $0.8950 \mathrm{~m}^{2} / \mathrm{g}$.

Table 1. Elemental analysis before and after adsorption

\begin{tabular}{|c|c|c|c|}
\hline Element Symbol & Element Name & $\begin{array}{c}\text { Weight } \\
\text { Concentration } \\
\text { (Before) }\end{array}$ & $\begin{array}{c}\text { Weight } \\
\text { Concentration } \\
\text { (after) }\end{array}$ \\
\hline $\mathrm{C}$ & Carbon & 92.1 & 53.8 \\
\hline $\mathrm{O}$ & Oxygen & 7.3 & 20.8 \\
\hline $\mathrm{Cu}$ & Copper & 0.0 & 0.0 \\
\hline $\mathrm{Pb}$ & Lead & 0.0 & 57.1 \\
\hline
\end{tabular}
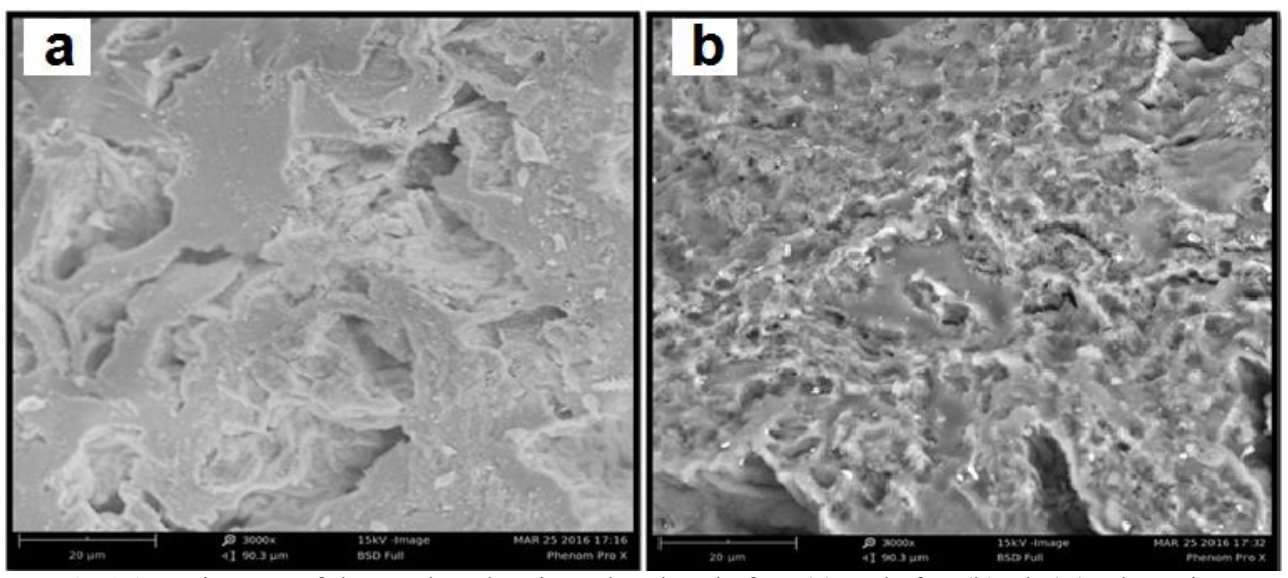

Fig 1 SEM images of the produced activated carbon before (a) and after (b) $\mathrm{Pb}$ (II) adsorption (3000X)

Results of FTIR analysis for the produced activated carbon is presented in Fig. 2. Spectra at 3406.59, 2917.58, 1610.44, 1113.89, 792.92, and $614.60 \mathrm{~cm}^{-1}$ represented O-H stretching, carboxylic/phenolic stretching bands, primary amine N-H bending, C-C stretching vibration, aromatic $\mathrm{C}-\mathrm{H}$ out-of-plane bending, and alkyne $\mathrm{C}-\mathrm{H}$ bending, respectively [26]. The decreased intensities of the peaks after adsorption of $\mathrm{Pb}$ (II) on the activated carbon showed that these functional groups got involved during the adsorption process [27].

\subsection{Effect of $\mathrm{pH}$}

Fig. 3 shows the activated carbon efficiencies in the removal of $\mathrm{Pb}$ (II) within various $\mathrm{pH}$ values (2-8). It can be observed that the highest removal efficiency was obtained at $\mathrm{pH} 6$ (45.53\%). The uptake capacity of $\mathrm{Pb}$ (II) was $9.60 \mathrm{mg} / \mathrm{g}$ at this $\mathrm{pH}$. Adsorption of $\mathrm{Pb}$ ions enhanced as $\mathrm{pH}$ increased to the optimum value and then showed a decline [28]. These results suggested that the adsorption of $\mathrm{Pb}$ ions on the activated carbon was mainly because of ionic attraction. The adsorbent consisted of weakly acidic and basic functional groups, thus as $\mathrm{pH}$ value increased the activated carbon surface became more negatively charged. At optimum $\mathrm{pH}(=6)$, ligands exposed with negative charges were available in the highest concentrations, but the amount of competing for hydrogen ions was in the lowest level which resulted in greater binding of the cation heavy metals to the weak acidic groups. Further increases in $\mathrm{pH}$ value decreased adsorption of the metal ions may be due to precipitation and lower polarity of $\mathrm{Pb}$ (II) at higher $\mathrm{pH}$ values [28]. 


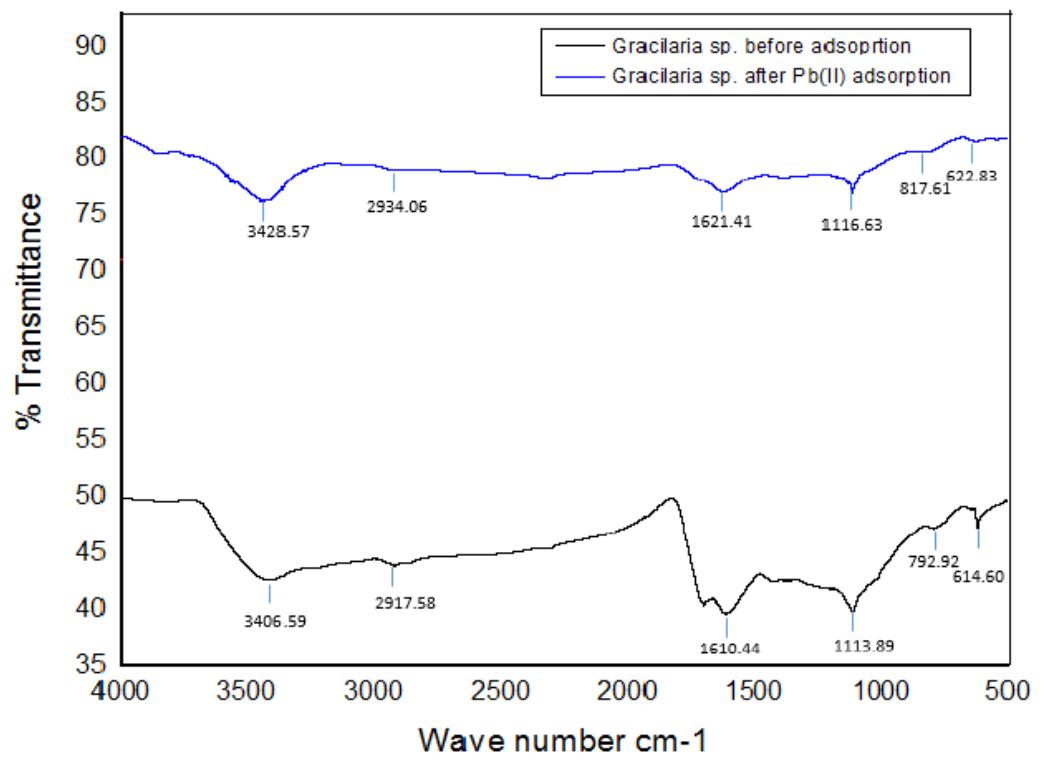

Fig 3 FTIR spectra before and after adsorption

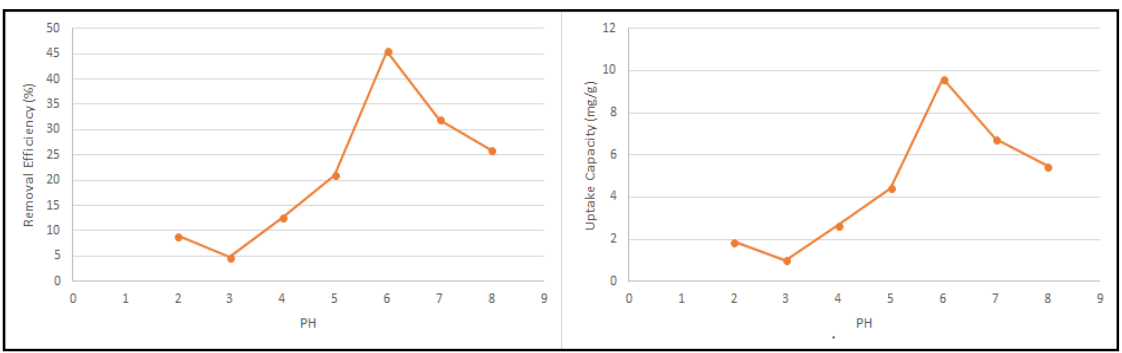

3.3

\section{Effect of contact time and ion concentration}

Fig 2 Effect of $\mathrm{pH}$ on $\mathrm{Pb}$ (II) adsorption

Fig. 4 shows the effect of contact time on adsorption of $\mathrm{Pb}$ (II) by the produced activated carbon. It was found that the equilibrium time for the ions adsorption was 30 minutes which is similar to study done by Jalai et.al using non-living biomass[29]. At optimum contact time, the available pores on adsorbents are fully occupied by adsorbate molecules/ions causing the removal to not significantly change and adsorption process already reached equilibrium [30], Fig. 6 shows the effect of initial concentration of metals ions on removal efficiency at optimum contact time. Percentage of the metal ions removal decreased with increasing initial ions concentration. This can be attributed to saturation of the adsorbent binding site and insufficient surface area to accommodate more metal ions available in the solution. At lower concentrations, all metal ions could react with the available binding site resulting in high removal efficiencies. 


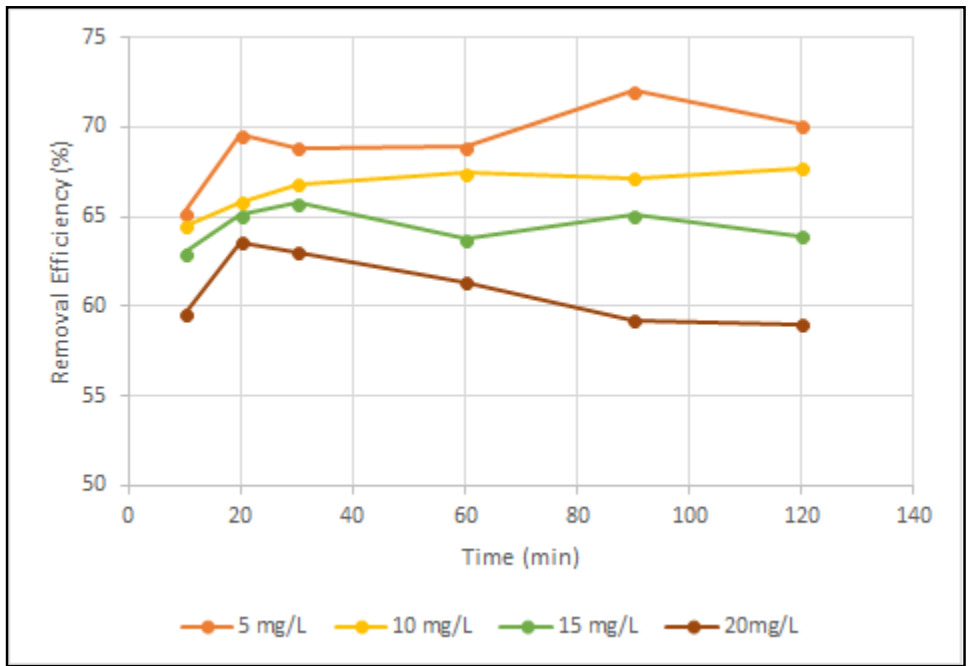

Fig 4 Removal Efficiency (\%) of $\mathrm{Pb}$ (II) at different initial metals ion concentration and contact time

Fig 5

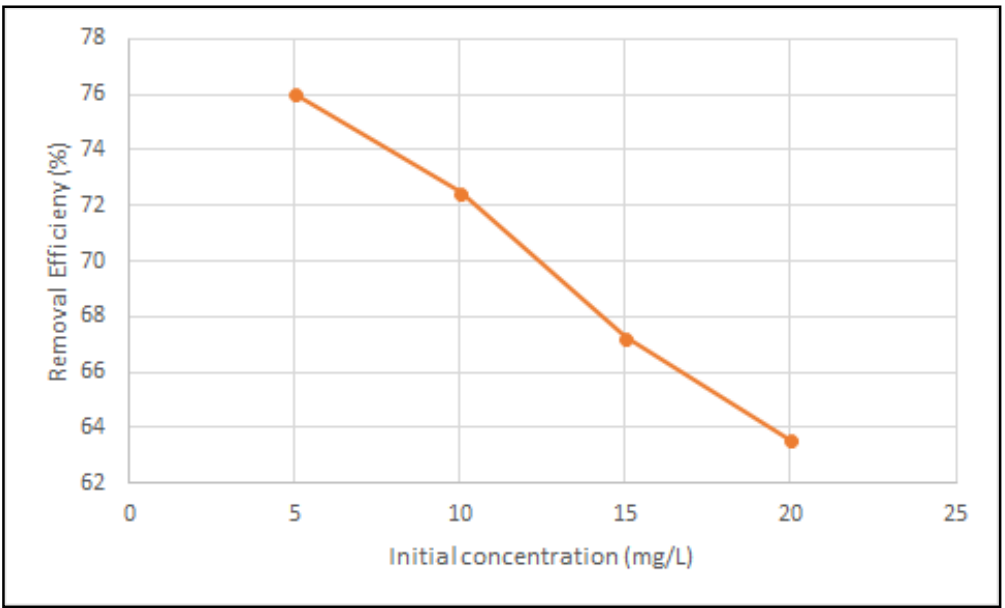

Removal Efficiency (\%) of $\mathrm{Pb}$ (II) at different initial metals ion concentration and optimum contact time

\subsection{Effect of adsorbent dosage}

Fig. 6 presents the removal efficiency per unit weight of the produced adsorbent. It was observed that the removal efficiency of $\mathrm{Pb}$ (II) increased with the increase in adsorbent dosage from 1 to $3 \mathrm{~g} / \mathrm{L}$. There were insignificant changes when the dosage exceeded $3 \mathrm{~g} / \mathrm{L}$ with removal efficiency of $63.11 \%$. 


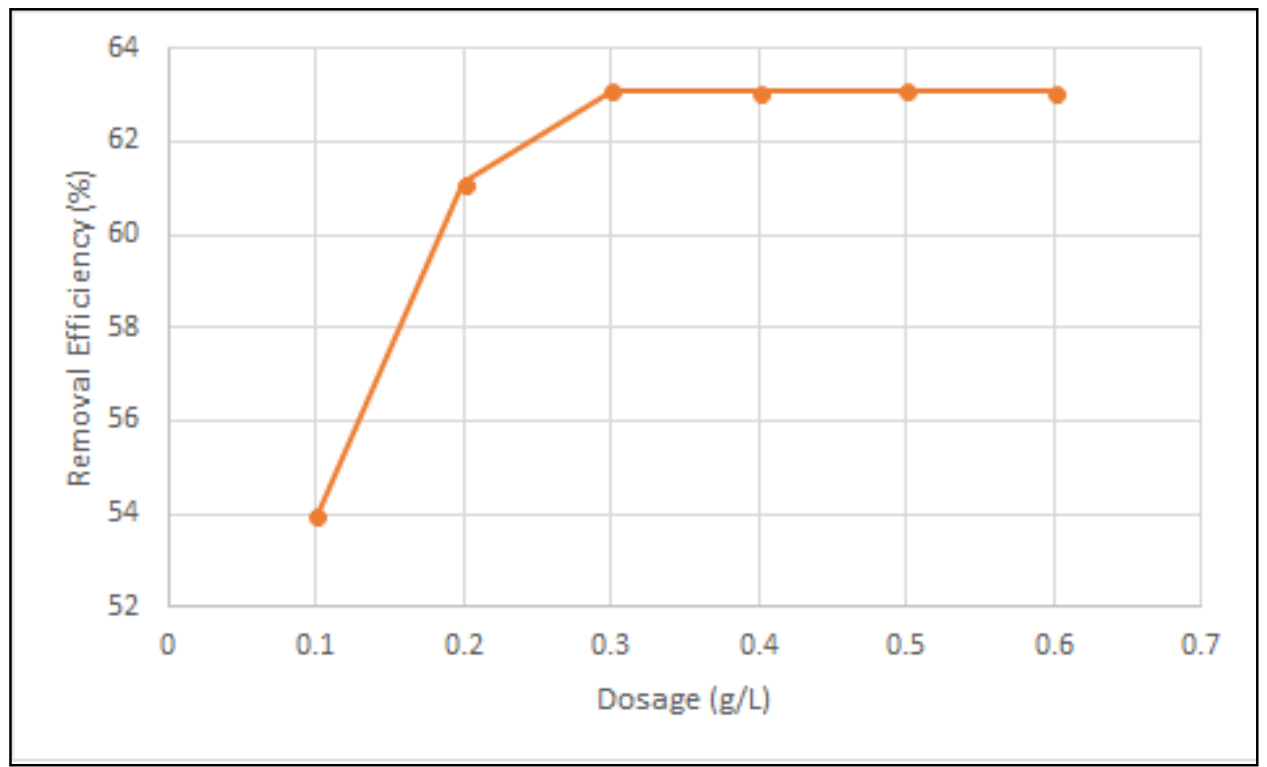

Fig 6 Removal Efficiency (\%) of $\mathrm{Pb}$ (II) at different adsorbent dosages

\section{Conclusion}

Red algae activated carbon was prepared and characterized for the removal of lead from synthetic solution. The presence of porosity was indicated by SEM and BET analysis. The chemical function groups were illustrated by FTIR. The study showed that parameter such as $\mathrm{pH}$, contact time, initial lead concentration, and adsorbent dosage have a significant effect on the uptake capacity. The maximum lead uptake capacity was obtained at pH 6 and operation time of $30 \mathrm{~min}$. The investigation showed the potential of macroalgae-derived activated carbon as an efficient low-cost adsorbent for removal of lead ions.

The authors are grateful for the financial support of Short-Term International Research Fund STIRF (0153 AAD-75), Universiti Teknologi Petronas, and the fishery department of Kedah.

\section{References}

[1] M. K. Aroua, S. P. P. Leong, L. Y. Teo, C. Y. Yin, and W. M. A. W. Daud, "Realtime determination of kinetics of adsorption of lead(II) onto palm shell-based activated carbon using ion selective electrode," Bioresour. Technol., 99, 13, pp. 5786-5792 (2008).

[2] G. Blázquez, M. A. Martín-Lara, G. Tenorio, and M. Calero, "Batch biosorption of lead(II) from aqueous solutions by olive tree pruning waste: Equilibrium, kinetics and thermodynamic study," Chem. Eng. J., 168, 1, pp. 170-177 (2011).

[3] H. Abadin, "Toxicological Profile for Lead," U.S Public Heal. Serv. Agency Toxic Subst. Dis. Regist., no. August, p. 582 (2007). 
[4] W. Griswold and S. Martin, "Human Health Effects of Heavy Metals," Environ. Sci. Technol., 15, pp. 1-6 (2009).

[5] M. A. Yahya, Z. Al-Qodah, and C. W. Z. Ngah, "Agricultural bio-waste materials as potential sustainable precursors used for activated carbon production: A review," Renew. Sustain. Energy Rev., 46, pp. 218-235 (2015).

[6] S. O. Lesmana, N. Febriana, F. E. Soetaredjo, J. Sunarso, and S. Ismadji, "Studies on potential applications of biomass for the separation of heavy metals from water and wastewater," Biochem. Eng. J., 44, 1, pp. 19-41 Apr. (2009).

[7] P. Zhou, J.-C. Huang, A. W. F. Li, and S. Wei, "Heavy metal removal from wastewater in fluidized bed reactor," Water Res., 33, 8, pp. 1918-1924, (1999).

[8] A. Esmaeili, P. Beirami, and S. Ghasemi, "Evaluation of the Marine Algae Gracilaria and its Activated Carbon for the Adsorption of Ni(II) from Wastewater," E-Journal Chem., 8, 4, pp. 1512-1521 (2011).

[9] F. Fu and Q. Wang, "Removal of heavy metal ions from wastewaters: A review," $J$. Environ. Manage., 92, 3, pp. 407-418 (2011).

[10] S. E. Bailey, T. J. Olin, R. M. Bricka, and D. D. Adrian, "A review of potentially low-cost sorbents for heavy metals," Water Res., 33,11, pp. 2469-2479, Aug. (1999).

[11] M. Imamoglu and O. Tekir, "Removal of copper (II) and lead (II) ions from aqueous solutions by adsorption on activated carbon from a new precursor hazelnut husks," Desalination, 228, 1-3, pp. 108-113, Aug. (2008).

[12] L. Ding, "Adsorption of Rhodamine-B from aqueous solution using treated rice huskbased activated carbon," Colloids Surfaces A Physicochem. Eng. Asp., 446, pp. 1-7, Apr. (2014).

[13] H. Demiral and C. Güngör, "Adsorption of copper(II) from aqueous solutions on activated carbon prepared from grape bagasse," J. Clean. Prod., 124, pp. 103-113, Jun. (2016).

[14] N. S. Nasri, U. D. Hamza, S. N. Ismail, M. M. Ahmed, and R. Mohsin, “Assessment of porous carbons derived from sustainable palm solid waste for carbon dioxide capture," J. Clean. Prod.,71, pp. 148-157, May (2014).

[15] Lavania-Baloo, N. Idayu, I. U. Salihi, and J. Zainoddin, "The use of macroalgae (Gracilaria changii) as bio-adsorbent for Copper (II) removal," IOP Conf. Ser. Mater. Sci. Eng., 201, 1, (2017).

[16] A. Salima, B. Benaouda, B. Noureddine, and L. Duclaux, "Application of Ulva 
lactuca and Systoceira stricta algae-based activated carbons to hazardous cationic dyes removal from industrial effluents," Water Res., 47, 10, pp. 3375-3388 (2013).

[17] W. M. Ibrahim, A. F. Hassan, and Y. A. Azab, "Biosorption of toxic heavy metals from aqueous solution by Ulva lactuca activated carbon," Egypt. J. Basic Appl. Sci., 3, 3, pp. 241-249 (2016).

[18] A. El Nemr, A. El-Sikaily, A. Khaled, and O. Abdelwahab, "Removal of toxic chromium from aqueous solution, wastewater and saline water by marine red alga Pterocladia capillacea and its activated carbon," Arab. J. Chem., 8, 1, pp. 105-117, (2015).

[19] A.A.Hamdy, "Biosorption of heavy metals by marine algae.," Curr. Microbiol., 41, 4, pp. 232-238, (2000).

[20] J. Wang and C. Chen, "Biosorbents for heavy metals removal and their future," Biotechnol. Adv., 27, 2, pp. 195-226, (2009).

[21] E. T. J. Johnston, P. E. Lim, N. Buhari, E. J. Keil, M. I. Djawad, and M. L. Vis, "Diversity of freshwater red algae ( Rhodophyta ) in Malaysia and Indonesia from morphological and molecular data," Phycologia, 53, pp. 329-341 (2014).

[22] M. H. Norziah and C. Y. Ching, "Nutritional Composition of Edible SeaweedGracilaria Changgi," Food Chem., 68, 1, pp. 69-76 (2000).

[23] S.-M. Phang, S. Shaharuddin, H. Noraishah, and A. Sasekumar, "Studies on Gracilaria changii (Gracilariales, Rhodophyta) from Malaysian mangroves," Hydrobiologia, 326, 1, pp. 347-352 (1996).

[24] X. Zhu, Y. Gao, Q. Yue, Y. Kan, W. Kong, and B. Gao, "Preparation of green algabased activated carbon with lower impregnation ratio and less activation time by potassium tartrate for adsorption of chloramphenicol," Ecotoxicol. Environ. Saf., 145, pp. 289-294 (2017).

[25] Y. N. Mata, M. L. Blázquez, A. Ballester, F. González, and J. A. Muñoz, "Characterization of the biosorption of cadmium, lead and copper with the brown alga Fucus vesiculosus," J. Hazard. Mater., 158, 2-3, pp. 316-323 (2008).

[26] M. Rafatullah, O. Sulaiman, R. Hashim, and A. Ahmad, “Adsorption of copper (II), chromium (III), nickel (II) and lead (II) ions from aqueous solutions by meranti sawdust," J. Hazard. Mater., 170, 2-3, pp. 969-977 (2009).

[27] P. SenthilKumar, S. Ramalingam, V. Sathyaselvabala, S. D. Kirupha, and S. Sivanesan, "Removal of copper(II) ions from aqueous solution by adsorption using cashew nut shell," Desalination, 266, 1-3, pp. 63-71 (2011). 
[28] A. Saeed, M. W. Akhter, and M. Iqbal, "Removal and recovery of heavy metals from aqueous solution using papaya wood as a new biosorbent," Sep. Purif. Technol., 45, 1, pp. 25-31 (2005).

[29] R. Jalali, H. Ghafourian, Y. Asef, S. J. Davarpanah, and S. Sepehr, "Removal and recovery of lead using nonliving biomass of marine algae," J. Hazard. Mater., 92, 3, pp. 253-262 (2002).

[30] Y. Li, "Removal of lead from aqueous solution by activated carbon prepared from Enteromorpha prolifera by zinc chloride activation," J. Hazard. Mater., 183, 1-3, pp. 583-589 (2010). 